\title{
THE IMPLEMENTATION OF “TRANSFORMATIONAL LEADERSHIP” IN DEVELOPING ACADEMIC QUALITY (A CASE STUDY AT UII YOGYAKARTA)
}

\author{
Bambang Ismaya $\mathrm{a}^{\mathrm{a}^{*}}$ \\ ${ }^{a}$ Teacher Training Faculty Universitas Singaperbangsa Karawang \\ Jl. HS. Ronggo Waluyo, Puseurjaya., Kabupaten Karawang, Indonesia bais1251@yahoo.com
}

\begin{abstract}
Transformational leadership supports higher education to frame their attitudes to shift their university forward. It has four leader higher education characteristics. Of these, idealized influence is defined as leader's behavior and the follower's attributions about the leader. Inspirational motivation refers to the ways by which transformational leaders motivate and inspire those around them. Individualized consideration represents the leader's continuing effort to treat each individual as a special person and act as a mentor; who attempts to develop their potential. Finally, intellectual stimulation represents the leader's higher education effort to stimulate followers to be innovative and creative to define problems and approach them in new ways. It is considered that who demonstrate these leader higher education characteristics of transformational leadership have effects on satisfaction leader University UII Yogyakarta and better performance at university. Therefore, this study purposes to discover the level of transformational leadership that higher education demonstrate at higher education during their administrative practices on daily basis. Results reveal that university demonstrate high level of characteristics of transformational leadership in terms of idealized influence, inspirational motivation, individualized consideration and intellectual stimulation behaviors.
\end{abstract}

Keywords: Higher education, Transformational leadership

\section{INTRODUCTION}

Higher Education as one form of formal organization consists of elements of purpose, set of people, and the existence of the hierarchy of authority. To be able to achieve the objectives that have been set, as well as to motivate and motivate the people involved in the institution, it is necessary for a leadership to state that leadership or leadership means to guide, meaning proces of managing organization, the process that takes place in organizational control. Effective leadership style. Much needed in an effort to improve performance. Employees in the achievement of the goals of higher education, thus the leadership style can be a good guideline.in an effort to improve employee performance. [1]

The Indonesian Islamic University is intensively reforming leaders at the Rectorate, Faculty, and Programs level in improving the quality and consistency of its leadership in its transformational style. Leadership by [2] is what leaders do. "Leadership is the process of leading a group and influencing the group in achieving its goals". Leadership is the process of leading a group and influencing the group to achieve its goals.

Leadership is always exciting in every job right now. In fact, the most important aspect is human behavior. 
This means giving a positive direction for the use of human resources and bringing out the best in a man. Thus leadership can be broadly defined as the relationship between individuals and groups built around some common interests in which groups behave in a manner directed or determined by leaders.

Transformational leadership is transformational leadership able to unite all subordinates and able to change the beliefs, attitudes, and personal goals of each subordinate in order to achieve goals, even beyond the set goals. [3]

However Beauchamp et al. [4] made significant progress in applying transformational leadership to the educational context. In the transformational leadership literature some researchers have combined multilevel factor analysis, the specific size development context, and the respondents of specific items when developing a certain size. Thus, researchers have highlighted the importance of considering contexts when designing transformational leadership steps.

Accountability in higher education has become a challenging issue for higher education institutions. As a continuation of this issue, higher education requires new concepts of management including how to determine good performance indicators in accordance with the values developed within the organization, through the implementation of transformational leadership in the development of academic quality. [5] argues that leadership leads to the greatest impact on performance. Such opinions can be contextualized in transformational leadership of leaders who have an impact on the performance of higher education leaders.

In this case, academic leaders such as university administrators, deans, academic coordinators, and even heads of programs play an important role in enhancing the culture of excellence to attract the most able to motivate existing academics.

Judging from the transformational style applied in UII Yogyakarta that they are able to bring high education that has high competitiveness at both national and international level, in the application of its leadership using "Idealized Influence", "Inspirational Motivation", "Intellectual Stimulation", "Individual Consideration" So based on the description of the phenomenon of the problems mentioned above, the authors are interested to conduct research with the title "The Implementation of Transformational Leadership in the Development of Academic Quality (Case Study at UII Yogyakarta)"

\section{LITERATURE REVIEW}

The transformational leadership theory was formulated by Burns, a presidential biographer and biographer [6]. In transactional leadership, leaders lead through social exchange, offering rewards for increased productivity, while transformational leadership moves the focus of the leader's needs for followers' needs [7].

"Transformational leadership theory is all about leadership that creates positive change in the followers whereby they take care of each other's interests and act in the interests of the group as a whole" [8] (Warrilow, 2012, hal. 356).

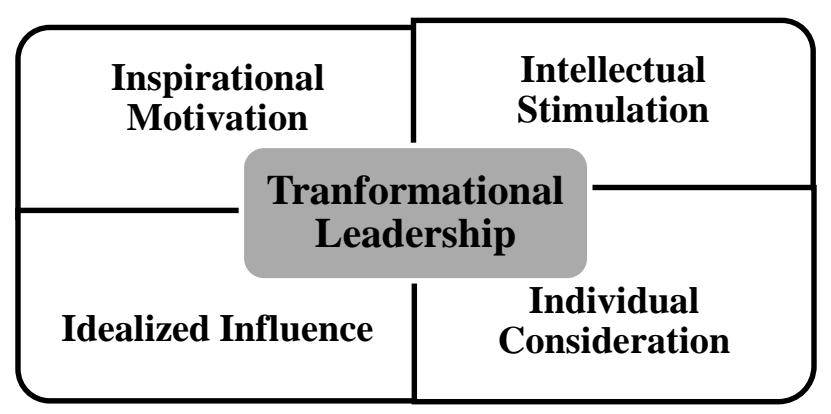

Figure 1: Transformational Leadership Model

From the explanation of this picture that the theory of transformational leadership is all about leadership that creates positive change in followers where they take care of each other's interests and act in the interest of the group as a whole, here also the dimension of transformational leadership is Ideal influence; Leaders behave as role models for their followers; They become admired, respected and trusted. Inspirational motivation: inspirational transformational leaders motivate in the eyes of their 
subordinates by giving meaning and challenge to their followers. Intellectual stimulation: intellectually stimulating leaders awaken in subordinates an awareness of problems, the recognition of their beliefs and values and their awareness of their own thoughts and imaginations. Individual considerations: leaders with individual considerations will give personal attention, treat each employee individually, and as a coach for his subordinates. These are all elements of the transformational leadership style dimension.

The characteristics of transformational leadership described by [9] are:

1. Charismatic leaders: give vision and sense of mission, instill pride and gain respect and trust

2. Ideal influence; Leaders behave as role models for their followers; They become admired, respected and trusted. Leader behavior is consistent rather than arbitrary, and leaders take risks. Leaders demonstrate high standards of ethical and moral conduct and avoid using things that are negative for personal gain.

3. Inspirational motivation: transformational leaders who are inspirational and motivating in the eyes of their subordinates by giving meaning and challenge to their followers.

4. Intellectual stimulation: intellectually stimulating leaders awaken in subordinates an awareness of problems, the confession of their beliefs and values and their awareness of their own thoughts and imaginations.

5. Individual considerations: leaders with individual considerations will give personal attention, treat each employee individually, and as a coach for his subordinates.

Bernard Bass, interested in the transformational approach, began to develop transformational leadership theories and undertook a series of empirical studies exploring nature and effects, finally being published in 'Leadership and Performance Beyond Expectations [10].

The [11] stated about the transformational leadership style that is: Transformational leadership is a leadership that has a vision for the future and is able to identify changes in the environment and is able to transform those changes into the organization, pioneer change and motivate, and build a solid teamwork, bringing renewed work ethos and management performance, courage and responsibility for leading and controlling organization.

[12] defined transformational leadership as A process that motivates followers by appealing to higher ideas and morals values where the leader has a deep set of internal values and ideas and is persuasive at motivating followers to act in a way that sustains the greater good of his own interests. [13] defined transformational leadership as style of leadership in which the leader identifies the necessity of change, the inspiration, and executes of the change with the commitment of the members of the group.

Transformational leadership is particularly concerned with the idea of improvement. Bass asserts that transformational leadership will appear when a leader has the ability to:

a. Stimulates the spirit of colleagues and followers to see their work from new perspectives.

b. Lowering the vision and mission to the team and its organization.

c. Developing colleagues and followers at a higher level of ability and potential.

d. Motivate colleagues and followers to look at their own interests, so that it can be useful for the interests of the organization.

From the above definition, we conclude that transformational leadership style is true leadership, where a leader motivates his subordinates to work maximally to achieve company goals and a leader 
who inspires and innovates the company (Fanni Adhistya Italiani, [14] 2014, p455)

\section{METHODS}

This study was carried out with a qualitative research design. These kinds of researches are used to gain indepth knowledge in a study ([15]; [16]. More specifically, the study employed an ethnographic research design in collecting data. Ethnographic designs, as [17] described them, "are qualitative research procedures for describing, analyzing, and interpreting aculture-sharing group's shared patterns of behavior, beliefs, and language that develop over time". As such, by using this research design and utilizing in-depth interviews, the study explored "culture-sharing" behaviors, beliefs, and language among teachers in Turkey context. Teachers' views were obtained through interviews with semistructured questions, as recommended by [18], to "get the subjects to freely express their thoughts around particular topics".

\section{a. Sample}

The participants of this study were 8 leader in heigher education Universiti Islamic Indonesia Yogyakarta. The participants were chosen by using apurposive sampling method described as the best used with small numbers of individuals or groups which may well be sufficient for understanding human perceptions, problems, needs, behaviors and contexts, which are the main justification for a qualitative audience research [19].

\section{b. Data Collection \& Analysis}

The data collection was using the "repertory grid" technique, which is a constructed interview method. This technique can best be characterized as a semistructured interview (face-to-face, computerized, or phone interview) in which the respondent is confronted with a triad of elements and then asked to specify some important ways in which two of the elements are alike and, thereby, different from the third ([19]; [20].
In this study, the data collection was using the following procedure. First, in an e-mail, the teachers were informed about the purpose of the study, and they were asked if they could participate in this research voluntarily. Those who were invited to take part in the research consented after being assured of the confidentiality of the data to be gathered from them. It was promised that their identities would be kept in secret and their names would not be mentioned in any part of the study or shared with anyone else. Second, an interview was planned on an agreed-upon day with those who accepted the invitation, and the participants were visited on that date. The interviews were both recorded and noted with their permission and each took approximately 50-60 minutes.

In order to analyze the data, the "content analysis" technique was employed. This type of analysis usually aims to analyze similar data on a topic and comment on it [21]; [22]; [23]. The first step taken in the data analysis process was the data organization procedures recommended by [18]. In organizing the data, the researcher revisited each interviewer and listened to each audiotape while reviewing the transcripts to ensure the accuracy of the data. Each participant's interview transcript was later analyzed according to the data analysis procedures described by [18], which call for development of coding categories, mechanical sorting of the data, and analysis of the data within each coding category. In this respect, each participant's interview was coded separately according to the participant's views on principals' transformational leadership behaviors as well as on various emerging themes and, later on repeated themes among the interviews was grouped into coding categories. It was done in three steps: category definition, exemplification, and codification regulation. First, the answers to each question were separated into meaningful categories, named, and coded. For example, the questions were conceptualized and named with four separate statements as transformational behaviors. These are idealized influence, inspirational motivation, individualized consideration and intellectual stimulation. In the second step, the conceptualized statements were brought together. In the third step, it 
was intended to avoid repetition. In the last phase, the identified results were explained and related to each other. It was also intended to build a cause-and-effect relationship among the separate parts. In this sense, the views of teachers were coded as T1, T2, T3, and T4.

The constant comparative approach [24] was used in the process of organizing and analyzing the data. The use of the constant comparative method results in the saturation of categories and the emergence of theory. Theory emerges through continual analysis and doubling back for more data collection and coding [18]; [24]. In this method, each set of data collected (interview transcripts) were reviewed in search of key issues, recurrent events, or activities in the data that became categories of focus. The data for each participant were reviewed multiple times for confirmatory and contradictory statements until the data were organized into satisfactory categories and sub-codes to address the research question. In order to fulfill the aforementioned purpose, the following semi-structured questions were raised:

1) How does UII leader apply aspect "Influence Charisma Ideal" in giving information and awareness at organization vision and mission led?

2) How does UII leader apply "Inspiring Motivation" in inspiring, motivating and modifying leaders' organization behavior in developing academic quality?

3) How does UII leaders carry out "stimulated intellectual" aspect in encouraging creativity and innovation among lecturer and its staffs in developing critical thinking and problem solving to build higher education better towards in developing lead academic quality?

4) How does UII leader perform "individual consideration" aspect in reflecting, thinking, and go on identifying employee needs, recognizing employee capacity, delegating its authority, giving attention, building guidance, and training follower specially and personally so that achieving directed organization that is led?

\section{A. Results}

The research results through observation, interviews, documentation found that the characteristics of ideal influence found on the leadership of the Foundation, Rector, Vice Rector, BPM, Dean, Vice Dean, Head of Department, Lecturer and Chairman of BEM UII Yogyakarta can be identified from the effort of UII Yogyakarta. The example of his subordinates in the process of reminding his subordinates to obedient in the implementation process of vision and mission during the meeting or guidance in front of UII leaders of Yogyakarta emphasized the subordinates to be actively involved in giving advice to subordinates when subordinates committed violations, especially in the process of vision and mission.

In the inspirational motivational character the leader expresses the attainment of the goal by using symbols that appeal to subordinates and express the goals in a simple way. Leaders are also expected to encourage, enthusiasm and optimism of every subordinate to implement the development of academic quality.

Through their verbal and symbolic behavior, transformational leaders can increase subordinate awareness of their abilities, internalization of organizational group values, and convenience to tasks or roles performed, which in turn can be a motivating force to improve subordinate performance in development Academic quality.

In describing the characteristics of intellectual stimulation, the attributes that need to be seen include acceptance and openness to criticism, acceptance and openness to new ideas, and ways of absorbing ideas and criticisms. New ideas and creative solutions in the process of handling problems are gathered from subordinates [25] Krause, 2009). This attribute can be seen by direct in-depth interviews to the leadership and staff of lecturers who become subordinates to get a view of subordinates to the characteristics of his boss. 
The leader as the person responsible in implementing the development of academic quality at UII Yogyakarta must be open to new ideas and criticism from both the faculty, department and faculty staff. This is necessary so that leaders can see opportunities for improvement in the development of academic quality at UII Yogyakarta. Likewise leadership against subordinates. Based on the results of in-depth interviews and document review of informants, it can be illustrated that the leadership of Islamic University of Indonesia Yogyakarta has an attitude of openness to any new ideas and criticism from subordinates. Among the form of acceptance of leadership to new ideas and criticism at UII Yogyakarta is the openness of leadership to new ideas and criticism of the implementation of academic quality development submitted by subordinates.

Leaders at UII Yogyakarta consider that the new ideas and criticisms submitted by the workers is a part that must be accepted as a logical consequence in the process of improving performance in the development of academic quality at UII Yogyakarta. This indicates that the leadership in UII Yogyakarta already has attributes of intellectual stimulation characteristics. [26]

\section{B. Discussion}

In describing the characteristics of intellectual stimulation, the attributes that need to be seen include acceptance and openness to criticism, acceptance and openness to new ideas, and ways of absorbing ideas and criticisms. New ideas and creative solutions in the process of handling problems are gathered from subordinates. [25] This attribute can be seen by direct in-depth interviews to the leadership and staff of lecturers who become subordinates to get a view of subordinates to the characteristics of his boss.

The leader as the person responsible in implementing the development of academic quality at UII Yogyakarta must be open to new ideas and criticism from both the faculty, department and faculty staff. This is necessary so that leaders can see opportunities for improvement in the development of academic quality at UII Yogyakarta. Likewise leadership against subordinates. Based on the results of in-depth interviews and document review of informants, it can be illustrated that the leadership of Islamic University of Indonesia Yogyakarta has an attitude of openness to any new ideas and criticism from subordinates. Among the form of acceptance of leadership to new ideas and criticism at UII Yogyakarta is the openness of leadership to new ideas and criticism of the implementation of academic quality development submitted by subordinates.

Meanwhile, in terms of conducting supervision of the implementation of academic quality development, the leaders have shown it, when conducting supervision of academic quality target targets, leaders also take the time to conduct supervision on the behavior of subordinates in carrying out academic quality development. Adequate supervision by the leadership is a proactive step leader in developing academic quality. Adequate supervision also implies that leaders have the ability to identify and improve subordinate character (s) in the development of academic quality. However, the best approach in implementing academic quality development is not the robustness of the oversight process, but it should be emphasized on the creation of an effective quality assurance system to reduce errors in the understanding of the academic quality development process.

\section{CONCLUSION/RECOMENDATION}

As a conclusion, UII leader apply aspect "Influence Charisma Ideal" in giving information and awareness at organization vision and mission by emphasizing the subordinates to be actively involved in giving advice to subordinates when subordinates committed violations, especially in the process of vision and mission.

Furthermore, the leadership of Islamic University of Indonesia Yogyakarta has an attitude of openness to any new ideas and criticism from subordinates.

Moreover, Leaders at UII Yogyakarta consider that the new ideas and criticisms submitted by the workers is a part that must be accepted as a 
logical consequence in the process of improving performance in the development of academic quality at UII Yogyakarta. This indicates that the leadership in UII Yogyakarta already has attributes of intellectual stimulation characteristics

\section{REFERENCES (Examples)}

[1] Endri Sukmana, Gede Adyana Sudibia, (2015), "Pengaruh Kepemimpinan Transformasional, Motivasi Dan Burnout Terhadap Kinerja Karyawan Outsourcing Rri Mataram" E-Jurnal Manajemen Unud, Vol. 4, No. 8, 2015 : 23332349 ISSN: 2302-8912.

[2] Robbins, Stephen P. Dan Coulter, Mary. (2010). "Manajemen". Edisi Kesepuluh. Jakarta: Penerbit Erlangga.

[3] Fanni Adhistya Italiani. (2013). "Pengaruh Gaya Kepemimpinan Transformasional Dan Transaksional Terhadap Kinerja Pegawai Departemen Sdm Pt. Semen Gresik (Persero) Tbk". Jurnal Ilmu Manajemen | Volume 1 Nomor 2 Maret 2013

[4] Beauchamp, M. R., Barling, J., \& Morton, K. L. (2011). "Transformational Teaching and Adolescent SelfDetermined Motivation, Self-Efficacy, and Intentions to Engagein Leisure Time Physical Activity: A Randomised Controlled Pilot Trial”. Applied Psychology: Health and Well-Being, 3 , 127-150. doi:10.1111/j.17580854.2011.01048.x

[5] Sedarmayanti. (2011). "Membangun Dan Mengembangkan Kepemimpinan Serta Meningkatkan Kinerja Untuk Meraih Keberhasilan". Bandung: PT Refika Aditama.

[6] Smith, M. (2011). Are you a transformational leader?. Nursing Management (Springhouse), 42(9), 4450.

[7] Cecily Ward, (2011), "Transformational Leadership Styles among Leaders in Singapore Schools: A Study of Gender Differences" International Leadership Journal Global Leadership, Singapore.

[8] Warrilow S (2012). Transformational leadership theory. Ezine articles [online] Available at: http;//ezinearticles.com?transformationalleadershiptheory. [Accessed November 28 2012]

[9] Norshidah Nordin, (2013), "Transformational Leadership Behaviour And Its Effectiveness Outcomes In A Higher Learning Institution", Journal Of Integration Knowledge.

[10] Lauren Mawn. (2012). "Transformational Leadership in Higher Education Lecturing". Bangor University.

[11] Tim Dosen Administrasi Pendidikan Universitas Pendidikan Indonesia. (2009). "Manajemen Pendidikan". Bandung: Alfabeta
[12] Doody, O., \& Doody, C. (2012). "Transformational leadership in nursing practice". Br J Nursing, 21(20),12121218.

[13] Northouse, Peter G. (2013). Leadership theory and practice $6^{\text {th }}$ edition. SAGE Publishing House: Los Angeles, USA.

[14] Fanni Adhistya Italiani. (2014). "Pengaruh Gaya Kepemimpinan Transformasional Dan Transaksional Terhadap Kinerja Pegawai Departemen Sdm Pt. Semen Gresik (Persero) Tbk”. Jurnal Ilmu Manajemen | Volume 1 Nomor 2 Maret 2014

[15] Denzin, Norman K. \& Lincoln, Yvonna S. (2005). The SAGE handbook of qualitative research $4^{\text {th }}$ edition. SAGE Publishing House: Los Angeles, USA.

[16] Marshall, C. \& Rossman, G.B. (2006). Designing qualitative research $4^{\text {th }}$ edition. Thousand Oaks, CA.

[17] Creswell, JW. (2005). Educational research: planning, conducting, and evaluating quantitative and qualitative research. Upper Saddle River: NJ.

[18] Bogdan, R., \& Biklen, S.K. (1998). "Qualitative research for education (3rded.)" Boston : Allyn \& Bacon. Inc.

[19] Bailey, K.D. (1994). Methods of social research $4^{\text {th }}$ edition. The Free Press: NY.

[20] Kerkhof, Ad., Apter, Alan. \& Grimland, Meytal. (2006). The phenomenon of suicide bombing: a review of psychological and nonpsychological factors. Crisis Journal Vol. 27(3):107-118 DOI 10.1027/0227-5910.27.3.107. Hogrefe \& Huber Publishers.

[21] Büyüköztürk, Ş., Kılıç Çakmak, E., Akgün, Ö.E., Karadeniz, Ş. ve Demirel, F. (2010). Bilimsel Araştırma Yöntemleri (5. Baskı). Ankara: PegemA Yayıncılık.

[22] Mayring, Ph. (2000). Qualitative Inhaltsanalyse. Grundlagen und Techniken (7th edition, first edition 1983). Weinheim: Deutscher Studien Verlag.

[23] Yıldırım, A. ve H. Şimşek (2010). Sosyal Bilimlerde Nitel Araştırma Yöntemleri (9. baskı), Ankara: Seçkin Yayınevi.

[24] Glaser,B.G. (1992). Basics of grounded theory analysis. Mill Valley, CA: Sociology Press.

[25] Krause, Philipp. (2009). Patterns of executive control over public spending. Paper presented at the LSE Conference "Emerging Research in Political Economy and Public Policy" London, 11 March 2009 . [Online] downloaded

http://www.lse.ac.uk/europeanInstitute/events/2008-

09/Krause.pdf on December 2012.

[26] Seltzer, Joseph. \& bass, Bernard M. (1990). Transformational leadership: beyond initiation and consideration. SAGE Journal of Management Vol. 6, Issue 4 pp. $693-703$. 
Bambang Ismaya/ Journal of Educational Administration Research and Review/Vol 01 .No. 1 June 2017 